\title{
Peran Ayah Muslim dalam Pembentukan Identitas Gender Anak Kampung Karanganyar, Brontokusuman, Mergangsan Yogyakarta
}

\author{
Wahyu Prastiyani \\ Universitas Muhammadiyah Yogyakarta \\ Email: wahyupras91@gmail.com
}

\begin{abstract}
This study aims to (1) know understanding of Muslim father against his role as a father, (2) identify Muslim father's role in the gender identity formation of children aged 6-8 years, and (3) determine the factors that influence Muslim father's role against gender identity formation of children aged 6-8 years. In this study, researchers used a qualitative descriptive research with an ethnographic approach. Collecting data using observation, interviews, and documentation. The subjects consisted of five fathers (intact family) aged 30-40 years who had children aged 6-8 years. The results of this study are (1) understanding of Muslim father against his role as a father are as economic provider, protector, educator, dan nurtured mother; (2) Muslim father's role in the gender identity formation of children aged 6-8 years include friends sharing, role model, resource, and disciplinary; and (3) the factors that influence Muslim father's role against gender identity formation of children aged 6-8 years are (a) educational background of father, (b) background of ethnic/culture, (c) length of working time father, (d) awareness of the responsibilities of parenthood, (e) cooperation and mutual agreement, (f) knowledge of parenting fathers, $(g)$ the pride of the father on the child's success, (h) lack of closeness between father and son, (i) the mental health of the father.
\end{abstract}

Keywords: children, gender identity formation, muslim father's role

INTISARI

Penelitian ini bertujuan untuk (1) mengetahui pemahaman ayah muslim terhadap perannya sebagai ayah, (2) mengidentifikasi peran ayah muslim dalam pembentukan identitas gender anak usia 6-8 tahun, dan (3) mengetahui faktor yang mempengaruhi peran ayah muslim terhadap pembentukan identitas gender anak usia 6-8 tahun. Dalam penelitian ini, peneliti menggunakan jenis penelitian deskriptif kualitatif dengan pendekatan etnografi. Pengumpulan data menggunakan teknik observasi, wawancara, dan dokumentasi. Subjek penelitian terdiri dari lima orang ayah (keluarga utuh) berusia 30-40 tahun yang memiliki anak usia 6-8 tahun. Hasil dari penelitian ini adalah (1) pemahaman ayah muslim mengenai perannya sebagai ayah adalah sebagai pemenuh kebutuhan ekonomi, pelindung, pendidik, dan pendamping ibu; (2) peran ayah muslim dalam pembentukan identitas anak usia 6-8 tahun meliputi teman berbagi, teladan, sumber pengetahuan, dan disciplinary; dan (3) faktor yang mempengaruhi peran ayah muslim terhadap pembentukan identitas gender anak usia 6-8 tahun antara lain: (a) latar belakang pendidikan ayah, (b) latar belakang etnis/budaya; (c) lama jam kerja, (d) kesadaran atas tanggung jawab sebagai orangtua, (e) kerjasama dan kesepakatan bersama, (f) ilmu parenting ayah, (g) kebanggaan ayah atas keberhasilan anak, (h) kurangnya keakraban antara ayah dan anak, serta (i) kesehatan mental ayah.

Kata kunci: anak, pembentukan identitas gender, peran ayah muslim 
$\mathrm{A}$ yah merupakan pemimpin dalam keluarga, mempunyai peran besar dalam membina dan mendidik seluruh anggota keluarganya, baik kepada istri (ibu) dan anak-anak. Peran ayah dalam keluarganya tidak hanya sebatas pencari nafkah untuk pemenuhan kebutuhan fisik keluarga. Lebih dari itu, ayah juga mempunyai peran penting dalam pendidikan anak-anak. Besarnya peran ayah dalam mendidik anak-anak sama besarnya dengan peran ibu. Hal ini berarti bahwa pengasuhan antara ayah dan ibu secara seimbang terhadap anak akan membentuk perilaku positif.

Dalam Islam, pendidikan anak bukanlah kewajiban ibu secara mutlak. AlQur'an justru menunjukkan besarnya peran ayah dalam mendidik anak. Dalam al-Qur'an terdapat dialog antara ayah dan anak sebanyak 14 kali. Sementara dialog antara ibu dan anak hanya 2 kali (http://thisisgender.com). Sebagai contoh dialog antara Luqman dan anaknya pada Surat Luqman ayat 13, 16, 17, dan 18. Dalam ayat-ayat tersebut, Luqman mengajarkan akidah dan akhlak kepada anaknya, mulai dari mengesakan Allah, melaksanakan shalat, amr ma'ruf dan nahi munkar, sabar dan tabah, sampai pada akhlak dan sopan santun dalam berinteraksi kepada sesama manusia (Shihab, 2002).

Sayangnya, budaya patriarki yang dianut sebagian masyarakat Indonesia menyebabkan peran tersebut belum berjalan secara maksimal. Peran laki-laki lebih banyak pada aspek publik, sementara perempuan pada aspek domestik. Sehingga, Indonesia menjadi fatherless country di mana peran atau keterlibatan ayah terhadap pendidikan keluarga masih minim. Fatherless di sini tidak hanya berarti tidak adanya sosok ayah secara fisik, melainkan juga ketidakhadiran ayah secara psikis. Misalkan saja dalam budaya Jawa, peran ayah hanya sebagai inisiator dan penanggung jawab pembiayaan keluarga, sementara ibu berperan sebagai guru bagi anak-anak yang mengajarkan semua hal kehidupan di masyarakat (Herusatoto, 2004).
Pada tahap tumbuh-kembang anak, anak-anak membutuhkan tidak hanya figur ibu melainkan juga figur ayah secara bersama, baik itu anak perempuan maupun anak laki-laki. Purwandari (2015) menemukan fakta bahwa anak laki-laki maupun perempuan tidak memiliki kedekatan dengan ayah. Ketidakhadiran sosok ayah akan meningkatkan konflik gender dan kebingungan gender pada anak di mana hal ini akan menyebabkan perilaku seksual menyimpang, yaitu homoseksual di kalangan pria maupun wanita (Sundari \& Herdajani, 2013). Ketidakpahaman ayah mengenai perannya menunjukkan bahwa ayah belum sepenuhnya mengerti dan memahami tentang identitas gender. Sebab, identitas gender tidak hanya mengenai perbedaan jenis kelamin antara laki-laki dan perempuan secara fisik, melainkan juga identitas, peran sosial, dan sebagainya (Reber \& Reber, 2010). Ketidakpahaman tersebut berakibat pada adanya fungsifungsi dalam rumah tangga yang belum berjalan dengan baik. Hal ini akan menimbulkan kesenjangan peran di dalam keluarga.

Beberapa penelitian tersebut mengungkap bahwa peran ayah memberi banyak dampak positif terhadap keluarga, seperti kontribusi terhadap pendapatan keluarga, dukungan untuk pasangan, serta kualitas waktu bersama anak (Baxter \& Smart, 2011). Selain itu, peran tersebut juga berdampak positif terhadap perkembangan motorik, emosional, kognitif, sosial anak (Wahyuningrum, 2011), serta meningkatkan prestasi akademik anak (Adamsons \& Jonhson, 2013). Temuan lain mengungkapkan bahwa keterlibatan ayah sangat terkait dengan penyesuaian perilaku anak (Adamsons \& Jonhson, 2013), berdampak positif pada harga diri anak ketika remaja (Kamila dan Mukhlis, 2013), dan pengungkapan diri remaja (Khoirunnisa \& Setyawan, 2013). Selain itu, keterlibatan ayah juga dapat mencegah perilaku seks pranikah, meskipun pengasuhan seksualitas yang dilakukan belum optimal (Setyawati \& Rahardjo, 2015).

Makusha, dkk (2013) mengungkap bahwa pria menggunakan masa kecil 
bersama ayah untuk pengalaman menjadi ayah di masa depan. Sementara itu, wanita menggunakan pengalaman masa kecil bersama ayahnya untuk membentuk harapan sosok ideal ayah bagi anakanaknya kelak dan juga untuk mempengaruhi ayah dari anak-anak. Dengan demikian, pria umumnya menjadi ayah yang baik jika ayah terlibat dalam kehidupan anak-anaknya dan memiliki kemampuan yang diperlukan untuk menjadi ayah yang baik. Selanjutnya, tidak adanya ayah biologis atau dalam situasi di mana ayah biologis tidak terlibat, ada sumber dukungan sosial lainnya (pria atau wanita) dan pemodelan peran alternatif untuk anak-anak. Hal tersebut berarti bahwa pengaruh dari peran ayah tidak terbatas pada pengalaman masa kecil pria dengan ayah biologis saja, tetapi juga mencakup peran tokoh masyarakat lainnya yang mengambil peran ayah dalam mendukung perkembangan anak (Setyawati \& Rahardjo, 2015).

Selanjutnya, posisi peneliti dalam hal ini adalah akan membahas tentang peran ayah muslim dalam pembentukan identitas gender pada anak usia 6-8 tahun. Pembahasan tersebut meliputi pemahaman ayah muslim terhadap perannya sebagai ayah, peran ayah muslim dalam pembentukan identitas gender anak usia 68 tahun, dan faktor yang mempengaruhi peran ayah muslim terhadap pembentukan identitas gender anak usia 6-8 tahun.

\section{Metode Penelitian}

Dalam penelitian ini, peneliti menggunakan jenis penelitian kualitatif dengan pendekatan etnografi. Sementara itu, pendekatan etnografi dipilih karena penelitian yang dilakukan berbasis masyarakat. Harris mengemukakan bahwa etnografi merupakan desain penelitian yang mendeskripsikan pola yang sama dari nilai, perilaku, keyakinan, dan bahasa dari kelompok yang berkebudayaan sama (Creswell, 2014). Lebih lanjut lagi, Freankel dan Wallen (1990) mengemukakan tujuan dari pendekatan etnografi, yaitu memperoleh gambaran umum mengenai subjek penelitian yang menekankan pada aspek pemotretan pengalaman keseharian individu dengan cara observasi dan wawancara kepada partisipan dan individu lainnya yang relevan (Creswell, 2010). Jadi, pendekatan ini dipilih untuk menemukan cara masyarakat yang akan diteliti dalam menggunakan keyakinan dan pengetahuan partisipan dalam membentuk identitas gender anak.

Lokasi penelitian ini adalah Kampung Karanganyar Kelurahan Brontokusuman Kecamatan Mergangsan. Kampung Karanganyar merupakan salah satu kampung urban di mana wilayah tersebut relatif heterogen dari segi tingkat pendidikan, latar belakang suku/etnis, dan jenis pekerjaan. Hal tersebut tentu akan memberi warna berbeda pada cara mendidik atau membentuk identitas gender anak. Semakin heterogen suatu wilayah, maka semakin tinggi tekanan untuk melaksanakan tanggung jawab dalam mendidik anak.

Dalam penelitian ini, peneliti memilih informan berdasarkan kriteria sebagai berikut.

1. Para ayah muslim yang memiliki anak usia 6-8 tahun, baik itu anak laki-laki dan/atau anak perempuan. Muslim dipilih karena alasan akademik, yaitu berkaitan dengan konsentrasi Psikologi Pendidikan Islam.

2. Keragaman suku/etnis. Dalam hal ini, suku ayah juga peneliti pertimbangkan karena budaya dari suku/etnis mempunyai warna berbeda dalam hal pengasuhan anak.

3. Keragaman tingkat pendidikan, mulai dari SD, SMP, SMA, sampai Perguruan Tinggi. Peneliti mengasumsikan bahwa semakin tinggi tingkat pendidikan orangtua, maka pola pikir dan cara yang digunakan dalam mendidik anak remaja akan lebih baik.

4. Lama waktu bekerja ayah, yaitu berapa lama waktu yang digunakan 
informan dalam bekerja. Peneliti mengasumsikan bahwa semakin lama waktu yang informan gunakan untuk bekerja, maka kesempatan untuk mendidik anak semakin sedikit. Artinya, dengan kesibukan informan dalam pekerjaannya, peran informan dalam membentuk identitas gender anak akan semakin sedikit.

Teknik pengumpulan data melalui observasi, wawancara, dan dokumentasi. Sementara itu, teknik analisis data dimulai dari pengumpulan data, klasifikasi data, reduksi data, triangulasi data, dan penarikan kesimpulan sementara.

\section{Hasil Penelitian dan Pembahasan}

\section{Kampung Karanganyar}

Kampung Karanganyar merupakan salah satu kampung padat penduduk yang terdapat di Kelurahan Brontokusuman. Kampung Karanganyar sendiri terbagi dalam empat RW, yaitu dari RW 16, RW 17, RW 18, dan RW 19. Luas wilayah kampung tersebut $\pm 10,63 \mathrm{Ha}$. Kampung ini terletak di sebelah barat sungai Code. Batas geografis utara Kampung Karanganyar adalah Jalan Kolonel Sugiono. Batas geografis sebelah barat adalah Jalan Sisingamangaraja. Batas geografis sebelah timur adalah Sungai Code. Sementara batas geografis sebelah selatan Kampung Karanganyar adalah RW 14 Karangkajen dan RW 23 Perumahan Green House. Secara keseluruhan, Kampung Karanganyar memiliki sekitar 692 KK dengan jumlah penduduk sekitar 2043 jiwa.

Kampung Karanganyar yang merupakan kampung padat penduduk, kebanyakan penduduknya berada di garis ekonomi menengah ke bawah, terutama warga RW 18 dan RW 19. Sebagian besar warga Kampung Karanganyar bekerja sebagai buruh harian lepas, seperti tukang ojek, penambang pasir, tukang parkir, buruh cuci, dan lainnya. Sementara itu, sebagian yang lainnya bekerja sebagai guru, Pegawai Negeri Sipil (PNS), karyawan swasta, dan wiraswasta. Banyaknya warga yang bekerja sebagai buruh lepas dikarenakan tingkat pendidikan warga Karanganyar yang berada pada tingkat SLTP dan juga SLTA.

Selain itu, penduduk Kampung Karanganyar didominasi oleh pendatang, yaitu sekitar $80 \%$ dari total jumlah penduduk. Orang-orang pendatang tersebut juga didominasi dari wilayah DIY sendiri, seperti Wonosari dan Kulon Progo. Selain itu, ada pula pendatang yang berasal dari kota-kota di Jawa Tengah, Jawa Barat, Jawa Timur, serta warga dari luar pulau Jawa. Oleh sebab itu, warga Kampung Karanganyar masih didominasi oleh suku Jawa.

Mayoritas penduduk Kampung Karanganyar beragama Islam dan sebagian kecil lainnya beragama Kristen dan Katolik. Dapat dikatakan bahwa 99\% penduduknya beragama Islam. Selain itu, organisasi Muhammadiyah juga mendominasi Kampung Karanganyar. Selanjutnya, untuk warga non-muslim, kegiatan keagamaanya dilaksanakan di gereja Jawa Mergangsan bagi penganut Kristen, sementara untuk Katolik di Gereja yang berada di Pugeran. Sementara itu, untuk Muslim, kegiatan keagamaan dilaksanakan di masjid-masjid yang berada di masing-masing RW.

\section{Pemahaman Ayah Mengenai Perannya sebagai Ayah}

Pemahaman para ayah atas perannya sebagai ayah menunjukkan seberapa jauh para ayah memahami peran gendernya. Sehingga, para ayah akan mendidik atau membentuk identitas gender anak sesuai dengan apa yang dipahami. Pemahaman tersebut salah satunya bisa dipengaruhi oleh budaya yang hidup di lingkungan sekitar. Walaupun Kampung Karanganyar merupakan daerah urban, namun begitu suku Jawa tetap mendominasi kampung tersebut. Hal ini dikarenakan urbanisasi yang terjadi di kampung tersebut berasal dari kabupaten-kabupaten di Daerah Istimewa Yogyakarta (DIY) dan sekitarnya, di mana budaya patriarki masih melekat. Oleh sebab itu, tidak heran jika data di lapangan menunjukkan bahwa umumnya peran sebagai ayah dipahami sebagai orang yang bertanggung jawab memenuhi kebutuhan ekonomi keluarga, baik itu kebutuhan pangan, papan, dan pendidikan.

Selain itu, pemahaman informan atas perannya sebagai pemenuh kebutuhan ekonomi tersebut juga mungkin dipengaruhi oleh tingkat ekonomi di lingkungan tempat tinggal. Salah satu ciri 
dari masyarakat padat penduduk di mana tingkat ekonominya berada di garis menengah ke bawah adalah orientasi pada pemenuhan kebutuhan ekonomi untuk hidup yang lebih baik. Oleh karena itu, peran untuk memenuhi kebutuhan ekonomi menjadi penting bagi individu untuk 'mentas' dari keadaan seperti itu dan berusaha membiayai pendidikan formal bagi anak-anak agar nasib anak lebih baik dari orangtuanya.

Sebagai kepala keluarga, salah satu peran ayah memang memenuhi kebutuhan ekonomi keluarga. Namun hal tersebut bukan satu-satunya peran penting yang harus ayah laksanakan. Seorang ayah juga harus mampu menjadi guru dan teladan yang baik bagi anak-anaknya, serta mampu membimbing istri sehingga dapat membantunya dalam mendidik anak-anak. Sebab, sebagai kepala keluarga, seorang ayah (suami) harus memastikan anggota keluarganya dapat hidup sejahtera, baik secara fisik maupun psikis serta di dunia maupun di akhirat.

Dalam budaya Jawa disebutkan bahwa 'Bapak kang ngukir jiwa, ibu kang ngayani batin anak' (Ayah yang membentuk keindahan jiwa, ibu yang mengisi dengan kekayaan batin anak). Pepatah tersebut menggambarkan bahwa tugas pokok ayah adalah membangun bentuk rohani anak sebagai wadah, sementara tugas pokok ibu adalah mengisi wadah rohani tersebut. Jika diibaratkan wadah rohani tersebut adalah pendidikan sejak kecil hingga dewasa, maka ayah yang akan membiayai pendidikan sang anak. Sementara itu, ibu mengisi ilmu pengetahuan hidup anak, seperti bahasa sehari-hari, adat-istiadat, simbol-simbol budaya, dan lain-lain (Herusatoto, 2004).

Usaha para orangtua (ayah) dalam mencari uang untuk memberikan pendidikan formal yang terbaik bagi anakanak merupakan salah satu kewajiban para orangtua. Namun hal tersebut menjadi kurang tepat jika hanya berhenti memasukkan anak ke sekolah sebagai jalan untuk mendidik anak. Sebab, dalam Islam pendidikan yang pertama dan utama bagi anak adalah keluarga, yaitu pendidikan dari kedua orangtuanya. Menyadari pentingnya hal tersebut, seorang informan sepakat bahwa mendidik anak harus atas kesepakatan bersama.

Sementara itu, seorang informan yang lainnya menyadari bahwa pentingnya perannya sebagai ayah sekaligus sebagai suami. Oleh sebab itu, selain ikut serta mendidik anak, suami pun mendidik sang istri agar dapat mendidik anak agar sesuai dengan tuntunan Islam. Hal ini terlihat dari cara suami istri tersebut membiasakan anak perempuannya memakai jilbab ketika bermain dengan teman-teman. Akbar dan Hawadi mengungkapkan bahwa dalam mengasuh anak, ayah dan ibu harus mempunyai filosofi manajemen yang sama terhadap anak. Hal ini akan meningkatkan konsistensi dan sarana anak dalam melakukan penyesuaian terhadap pendekatan kepada orangtuanya (Akbar \& Hawadi, 2001).

Shihab (2002) dalam tafsir dan penjelasan atas QS. At-Tahrim ayat 6 menyebutkan bahwa pendidikan dan dakwah harus bermula dari rumah. Kedua orangtualah yang bertanggung jawab terhadap anak-anak dan pasangan masingmasing sebagaimana masing-masing bertanggung jawab atas perilakunya. Hal tersebut berarti bahwa seorang ayah tidak cukup hanya memenuhi kebutuhan fisik keluarga, tetapi juga kebutuhan psikis (immaterial).

Senada dengan Shihab, Rahman (2015) menyebutkan bahwa orangtua wajib memberikan pendidikan yang baik dan religius, serta melatih anak agar berperilaku yang baik dan sopan, di mana hal tersebut wajib diajarkan tanpa memandang jenis kelamin anak. Lebih lanjut lagi, jenis pendidikan yang harus diberikan kepada anak untuk pertama kalinya adalah pendidikan agama, sebab orangtua memikul tanggung jawab besar untuk membentuk anak sesuai fitrahnya (Rahman, 2015). Hal ini sesuai dengan QS. Ar-Rum ayat 30: 


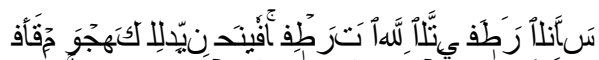

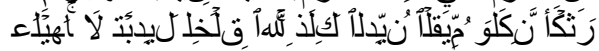

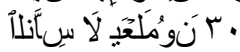

Terjemahan:

Maka hadapkanlah wajahmu dengan lurus kepada agama Allah., (tetaplah atas) fitrah Allah yang telah menciptakan manusia menurut fitrah itu. Tidak ada perubahan pada fitrah Allah. (Itulah) agama yang lurus., tetapi kebanyakan manusia tidak mengetahui (Departemen Agama RI, 2002).

Pendidikan agama yang diberikan orangtua sejak dini merupakan langkah awal orangtua (ayah) dalam membentuk identitas gender anak. Melalui pendidikan agama pula, identitas sebagai laki-laki dan identitas sebagai perempuan menjadi jelas. Sebab, Islam telah memberi pedoman secara jelas bagi pemeluknya bagaimana fitrah sebagai manusia.

Dalam masyarakat Jawa, peran ideal untuk laki-laki antara lain sebagai kepala keluarga yang bertanggung jawab untuk mencari nafkah bagi keluarga, pelindung, dan pengayom (Putri \& Lestari, 2016). Hal ini sejalan dengan temuan di lapangan oleh peneliti, di mana peran informan sebagai ayah selain sebagai pemenuh kebutuhan ekonomi adalah pelindung keluarga, penjamin kesejahteraan keluarga, dan pendidik anak sesuai kesepakatan bersama. Sebagai pelindung keluarga, seorang ayah (suami) harus berusaha memastikan semua anggota keluarganya selamat di dunia dan di akhirat. Oleh sebab itu, seorang ayah haruslah memiliki pengetahuan agama yang matang untuk memastikan hal tersebut.

Namun, kebanyakan informan memaknai peran pelindung sebagai menjaga anggota keluarga agar terhindar dari bahaya-bahaya (fisik) yang ada di sekitar lingkungan terdekat. Padahal, seorang ayah (suami) mempunyai tanggung jawab yang besar untuk melindungi anggota keluarganya dari siksa api neraka. Selain itu, ayah juga mempunyai kewajiban untuk Memberikan perlindungan kepada anak agar fitrah kesucian anak tidak pudar dan hilang. Itu artinya, seorang ayah tidak hanya melindungi anggota keluarganya dari bahaya-bahaya di dunia, melainkan juga melindungi anak agar terbebas dari neraka. Hal ini telah difirmankan Allah pada QS. AtTahrim ayah 6, yaitu:

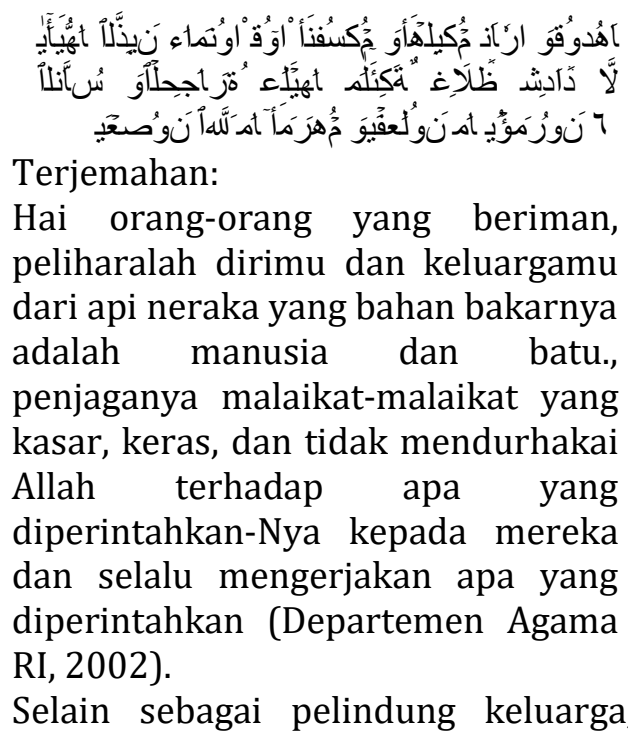
seorang ayah juga harus menjamin kesejahteraan anak, baik secara fisik maupun psikis. Hal ini penting agar tumbuh-kembang anak dapat berjalan secara wajar dan baik. Untuk menjamin kesejahteraan anak, maka kebutuhan dasar anak harus terpenuhi, yaitu: (a) kebutuhan biologis, (b) kebutuhan rasa aman, (c) kebutuhan kasih sayang, (d) kebutuhan rasa harga diri, (e) kebutuhan aktualisasi diri, (f) kebutuhan rasa keindahan, (g) kebutuhan rasa ingin tahu, (h) kebutuhan rasa sukses, dan (i) kebutuhan akan adanya kekuatan bimbingan (Anis, 2009).

Secara fisik, para informan memenuhi kesejahteraan anak dengan cara memberi makanan yang sehat sehingga kesehatan anak terjaga serta menyediakan tempat tinggal yang nyaman. Meskipun pada kenyataanya, lingkungan Kampung Karanganyar (terutama RW 18 dan RW 19) belum dapat dikatakan menjadi tempat tinggal yang nyaman. Rumah yang saling berdempetan dan sempitnya ruang terbuka untuk bermain, menjadi salah satu indikator tidak nyamannya tempat tinggal tersebut. Menyadari hal tersebut, salah satu informan berupaya untuk bisa pindah ke tempat hunian yang yang lebih nyaman, sehingga pertumbungan dan perkembangan anak dapat berjalan lebih baik.

Sementara secara psikis, kesejahteraan anak dipenuhi oleh para informan dengan cara menghabiskan waktu 
bersama anak untuk melakukan kegiatan bersama, seperti bermain, belajar, dan jalan-jalan. Hal ini dilakukan oleh para informan agar terjalin kedekatan antara ayah dan anak. Selain itu, juga agar anak merasakan kasih sayang dan perhatian dari ayahnya. Anis (2009) menyebutkan bahwa hubungan yang didasarkan pada kasih sayang akan membawa pada kenyamanan dan kedamaian, sehingga akan menghindarkan sifat egois dan setiap anggota keluarga akan berusaha mamnusiakan yang lainnya. Hal ini merupakan salah satu tujuan dari keluarga, yaitu sakinah seperti yang telah difirmankan Allah pada QS. Ar-Rum ayat 21, yaitu:

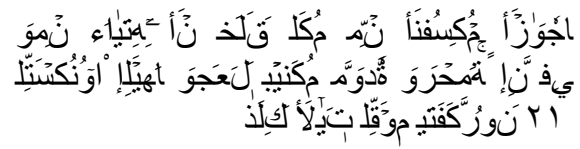

Terjemahan:

Dan di antara tanda-tanda kekuasaan-Nya ialah Dia menciptakan untukmu isteri-isteri dari jenismu sendiri, supaya kamu cenderung dan merasa tenteram kepadanya, dan dijadikan-Nya di antaramu rasa kasih dan sayang. Sesungguhnya pada yang demikian itu benar-benar terdapat tandatanda bagi kaum yang berfikir (Departemen Agama RI, 2002).

Selain pemahaman atas perannya sebagai ayah, keberhasilan membentuk identitas gender anak juga bergantung bagaimana seorang ayah dapat mengidentifikasi sifat/ciri dari masingmasing gender. Dalam budaya Jawa, citra perempuan yang ideal adalah yang memiliki sifat lemah lembut, penurut, tidak membantah, dan tidak melebihi laki-laki. Sementara itu, laki-laki yang ideal dicitrakan sebagai sosok yang serba tahu, panutan bagi perempuan, berpikir rasional, dan agresif (Raharjo dalam Putri dan Lestari, 2016).
Goode (Anis, 2009) mengungkapkan bahwa seseorang disadarkan akan adanya hubungan peran karena proses sosialisasi yang berlangsung sejak masa kanak-kanak, yaitu proses di mana anak akan belajar mengetahui apa yang dikehendaki oleh anggota keluarga lain dan akhirnya menimbulkan kesadaran tentang kebenaran yang dikehendaki. Begitupun mengenai identifikasi masing-masing gender. Melalui sosialisasi, para orangtua (ayah) membentuk identitas gender anak sesuai dengan apa yang orangtua pahami. Sehingga anak akan meyakini kebenaran akan identitas gender tersebut.

Dari pemahaman informan atas identifikasi gender dari masing-masing jenis kelamin, diperoleh bahwa laki-laki dicirikan sebagai sosok yang bertanggung jawab, lebih berani dari perempuan, serta mempunyai dedikasi dan wacana untuk kemajuan keluarga. Para informan sepakat bahwa anak laki-lakinya kelak adalah pemimpin bagi keluarga kecilnya. Oleh sebab itu, anak dipersiapkan untuk menjadi pemimpin yang mampu membimbing keluarganya. Sementara itu, perempuan dicirikan sebagai sosok yang patuh, dapat mendidik anak, pengayom keluarga, dan pendamping suami. Hal ini sesuai dengan pencitraan masing-masing jenis kelamin sesuai dengan budaya Jawa, di mana seluruh informan berlatar belakang budaya Jawa.

Sementara itu dalam Islam, seorang laki-laki (suami/ayah) adalah pemimpin, penjaga dan pelindung keluarganya. Selain itu, ia juga harus mengurus, mengatur, memelihara, dan mengasihi anak serta istrinya. Sebagai seorang ayah, ia berkewajiban menumbuhkan potensi anak dengan mendidik dan mengajar serta memenuhi kebutuhan fisik dan psikis anak. Sebagai seorang suami, ia berkewajiban menjaga dan memelihara istrinya dengan cara melindungi serta memberi nasihat yang baik dengan penuh kasih sayang (Anis, 2009). Hal ini telah diterangkan oleh Rasulullah SAW dalam hadits yang 
diriwayatkan oleh al-Nawawi dan Ibnu Hanbal.

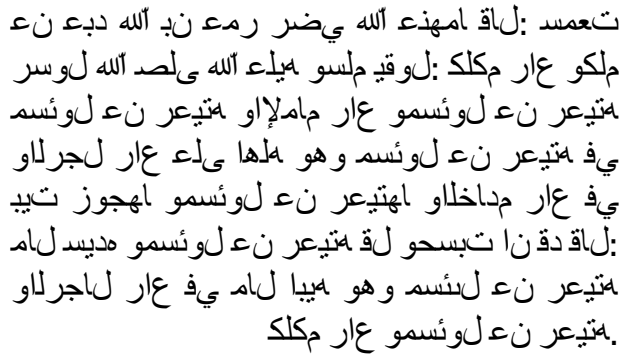

Terjemahan:

Dari Abdullah Inbu Umar r.a. berkata bahwa Rasulullah bersabda: Kamu adalah pemelihara dan kamu semua bertanggung jawab atas yang dipelihara. Imam itu pemelihara dan bertanggung jawab atas yang dipelihara. Suami itu adalah pemelihara keluarga dan ia bertanggung jawab atas pemeliharaannya itu. Buruh adalah pemelihara harta majikannya dan ia bertanggung jawab atas pemeliharaan itu. Berkata perawi: Aku mengira bahwa nabi benarbenar bersabda, orang laki-laki (anak) adalah pemelihara harta ayahnya dan ia bertanggung jawab atas pemeliharaannya itu (AnNawawi (1923); Ibnu Hanbal (tt) dalam Anis, 2009).

Dari hadis di atas juga diterangkan bahwa seorang istri adalah pemelihara rumah tangga suaminya. Selain itu, istri merupakan mahkota rumah tangga dan sebagai pendamping yang taat untuk suaminya. Tidak hanya suami yang berkewajiban mendidik anak, istri pun mempunyai kewajiban yang sama dalam mendidik anak. Seorang istri juga menjadi motivator bagi anak dan suaminya untuk menuju jalan yang lurus (Anis, 2009). Dengan demikian, ketika orangtua memahami akan identitas gendernya, maka orangtua pun akan memahami apa peran dan tanggung jawabnya sebagai orangtua. Dari pemahaman itu pula, ia pun akan mendidik anak-anaknya agar menjadi pribadi yang sadar akan identitas, peran, dan tanggung jawabnya di masa depan.

\section{Peran Ayah dalam Pembentukan Identitas Gender Anak}

Salah satu fungsi keluarga adalah fungsi pendidikan, yang meliputi penanaman, pembimbingan, atau pembiasaan nilai-nilai agama, budaya, dan keterampilan tertentu yang bermanfaat bagi anak. Keluarga mempunyai peran yang penting dalam perkembangan dan pertumbuhan anak, baik fisik maupun psikis (Anis, 2009). Melalui pendidikan yang ada di keluarga inilah anak mulai mengenal masyarakat sekitar, mulai mempelajari norma dan aturan, serta mulai meniru dan memandang orang tua sebagai sosok yang dijadikan model.

Ayah dan ibu memiliki peran yang sama besar dalam memberikan pendidikan kepada anak-anak. Hal ini karena tanggung jawab dalam mendidik anak-anak bukan hanya berada di tangan ibu atau ayah, melainkan tanggung jawab dari ayah dan ibu secara bersama-sama. Namun, ketika salah satu pihak tidak memungkinkan, maka salah satu pihak hendaknya merangkap kehadiran pihak lain. Maka dari itu, dapat dikatakan bahwa peran ayah juga sebagai pengganti peran ibu. Hal ini berarti bahwa apa yang ibu lakukan juga bisa dilakukan oleh ayah tanpa harus membedabedakan tugasnya.

Pentingnya peran ayah dalam pertumbuhan dan perkembangan anak, harus disadari oleh para ayah. Keterlibatan ayah dalam mendidik anak tidak terbatas dari aspek waktu, tetapi juga kualitas interaksi dan perhatian yang meliputi dimensi fisik, emosi, sosial, intelektual, moral, maupun otoritas. Dalam pembentukan identitas gender untuk anak usia 6-9 tahun, sosok ayah merupakan model identifikasi bagi anak laki-lakinya, di mana anak cenderung meniru semua aktivitas yang dilakukan oleh ayah (Kusumah \& Fitrianti, 2012). Sementara itu, bagi anak perempuan, ayah adalah sumber pegangan untuk persetujuan atas perilaku yang sesuai dengan jenis kelaminnya (Hurlock, 1978).

Lebih lanjut lagi, anak pada usia tersebut mulai menyadari bahwa ada perbedaan antara alat kelamin laki-laki dan perempuan. Anak mulai mengenal identitas dirinya bukan hanya dari alat kelamin yang 
dimilikinya tetapi juga perlakuan sekeliling anak. Anak perempuan akan mendapatkan mainan seperti boneka atau alat-alat masak-masakan, sedangkan anak laki-laki mendapatkan mainan mobil ataupun pesawat. Anak pun secara psikologis mulai merasakan pengaruh dari jenis kelaminnya. Anak laki-laki cenderung menjadi lebih sayang pada ibunya, sementara anak perempuan lebih sayang pada ayah. Anakanak mulai mempunyai keinginan ingin seperti ayah atau ibunya kelak (Graha, 2007).

Berikut ini adalah peran ayah muslim dalam pembentukan identitas gender anak usia 6-8 tahun di Kampung Karanganyar yang meliputi:

\section{Sebagai teman berbagi dan sumber pengetahuan}

Dalam hal ini, para informan memanfaatkan media majalah maupun acara-acara di televisi untuk menunjukkan perilaku yang boleh atau tidak boleh dilakukan. Hal ini merupakan salah satu cara yang cukup efektif mengingat televisi merupakan media yang dekat dengan anak-anak. Cara tersebut juga dapat menjadi pengawalan oleh para ayah pada tontonan anak-anak. Selain menunjukkan perilaku yang boleh dan tidak boleh, para ayah juga memberikan alasan mengapa suatu hal boleh dan tidak boleh dilakukan, sehingga anak menjadi paham dan mengerti tentang apa yang baik dan yang tidak baik untuk dia lakukan.

Pemberian pemahaman dan pengertian kepada anak mengenai apa yang boleh dan tidak boleh dilakukan merupakan salah satu tugas orangtua dalam memenuhi kebutuhan anak, yaitu kebutuhan rasa ingin tahu. Hal ini menjadi penting karena anak memiliki rasa ingin tahu yang besar terhadap sesuatu yang baru atau sesuatu yang belum ia ketahui. Selain itu, pada usia ini, anak belajar tentang benar dan salah melalui hukuman dan pemberian hadiah (Yuniarto, 2013). Jika anak dibiarkan melakukan kesalahan atau hanya dilarang tanpa memberi penjelasan, maka hal ini akan berdampak buruk pada perkembangan anak. Oleh sebab itu, orangtua (ayah) bertanggung jawab memenuhi kebutuhan tersebut melalui pengajaran kepada anaknya. Hal ini diungkapkan oleh seorang informan berikut ini:

“....yang jelas tidak harus sesuatu itu cuman sekedar di... kamu yes... boleh begini, kamu tidak boleh. Ada sesuatu yang kadang harus diterangkan. Harus diterangkan mengapa begini, mengapa begitu. Itu harus diterangkan mengapa begini, mengapa begitu... itu harus diterangkan mengapa biar dia juga apa... otaknya juga berjalan. Kadang orangtua itu pokoknya nggak boleh begini, harus begini itu nggak bisa" (Wawancara kepada Bapak Legimo).

Dalam hal ini, Anis mengungkapkan bahwa mengajar bertujuan untuk memberi pengetahuan kepada anak dan memberi penjelasan atas apa yang belum jelas, serta memberi jawaban atas pertanyaan anak (Anis, 2009). Hal ini telah diperintahkan Rasulullah SAW dalam hadis yang diriwayatkan oleh Ibnu Majah dari Ibnu Abbas ra, yaitu:

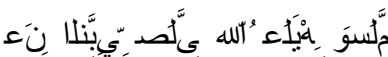

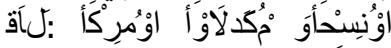


Terjemahan:

Nabi Shallallahu 'alayhi

wa Sallam bersabda,

"Muliakanlah anak-anak

kalian dan ajarkanlah

kepada mereka adab

yang baik." (Suwaid,

2010).

Dalam memberi pengetahuan mengenai hal yang boleh dan tidak boleh dilakukan oleh anak, para ayah tentunya juga harus mengenalkan agama kepada anak. Sebab, melalui ilmu agama inilah seseorang mampu membedakan tidak hanya yang baik dan buruk, melainkan juga yang benar dan salah. Islam telah memberi pedoman yang jelas kepada pemeluknya untuk membedakan antara yang haq dengan yang batil, seperti yang telah difirmankan Allah SWT dalam QS. Al-Furqan ayat 1:

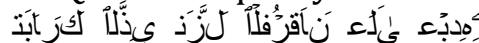

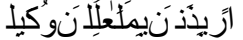

Terjemahan:

Maha suci Allah yang

telah menurunkan

Furqaan (Al-Quran)

kepada hamba-Nya

(Muhammad), agar dia

menjadi pemberi

peringatan kepada

seluruh alam (jin dan

manusia). (Departemen

Agama RI , 2002).

Selanjutnya, dalam memberi ilmu pengetahuan kepada anak, hendaknya para orangtua (ayah) memahami tahap perkembangan anak. Hal ini pun telah diajarkan oleh Rasulullah SAW bahwa seorang yang memiliki anak, maka hendaknya ia menjadi seperti anak itu, yaitu menjadi orangtua yang memahami anak, bersahabat dengan anak, serta menjadi teman bermain bagi anak (Rahman, 2015). Hal ini berarti bahwa dalam mengajari dan mendidik anak sesuai gendernya, hendaknya orangtua (ayah) memberikan contoh, penjelasan, atau nasihat yang mudah dipahami oleh anak. Kadang tidak mudah menjawab pertanyaan-pertanyaan anak yang sederhana tetapi jawabannya tidak sederhana, seperti cara berpakaian antara laki-laki dan perempuan, cara berperilaku, atau mengenai anatomi tubuh. Oleh sebab itu, para orangtua (ayah) menyadari bahwa belajar itu setiap waktu dan selamanya, sehingga ilmu yang dimiliki selalu terkini. Sebab zaman terus berubah dan tentunya cara mendidik anak pun disesuaikan dengan perkembangan zaman tersebut.

\section{Sebagai pembentuk disiplin}

Selain menjadi teman berbagi dan sumber pengetahuan bagi anak, para ayah juga mengajarkan tentang kedisiplinan kepada anak. Menurut informan, hal ini penting untuk dimiliki dalam mencapai kesuksesan di masa datang, seperti berikut ini:

"Ya saya cuma disiplin aja. Istilahe wayahe sekolah, sekolah. Wayahe belajar, belajar. Nanti wayah mainan $H P$... istilahe wifian itu ada sendiri-sendiri. Jadi harus tepat waktu, misalkan main sebelum Maghrib harus sudah pulang. Itu cara yang simpel kalau menurut karakter lakilaki lah. Yang jelas disiplin. Intinya disiplin dulu. Karena anak saya laki-laki, yang jelas itu. Yang sering saya dengar, orang sukses itu berawal dari disiplin. Disiplin waktu, disiplin apa-apa. Yang jelas memang yang paling menonjol, yang paling utama, kalau menurut saya memang disiplin itu" (wawancara kepada Bapak Tripurwanto).

Dalam hal ini Akbar dan Hawadi menyatakan bahwa melalui otoritas dan disiplin, ayah akan merangsang orientasi realitas anak. Ayah akan membebankan tugas pada 
setiap anggota keluarga. Dengan demikian, seorang ayah mendidik anaknya untuk melihat hidup secara realistis. Sementara itu, ibu memiliki kecenderungan untuk memberi kesenangan pada keinginan anak sebagai pendorong bagi anakanaknya (Akbar dan Hawadi, 2001).

Sementara

Lestari menyebutkan bahwa pendisiplinan merupakan salah satu bentuk dari upaya orangtua untuk mengontrol anak agar anak menguasai suatu kompetensi, melakukan pengaturan diri, menaati aturan, dan mengurangi perilaku-perilaku menyimpang atau berisiko (Lestari, 2012). Brooks (2011) menambahkan bahwa strategi disiplin verbal memiliki banyak manfaat. Keterampilan sosial dan emosional anak tumbuh sehingga mampu memahami aturan ketika orangtua bersikap tenang, memberikan alasan, serta menghindari ancaman dan paksaan fisik. Memaksa anak dengan teriakan dan kemarahan akan meningkatkan rasa frustrasi dan penolakan anak (Brooks, 2011).

Senada dengan di atas, Islam memerintahkan agar setiap muslim mempunyai kedisiplinan yang tinggi, seperti perintah salat tepat waktu, menaati segala yang diperintahkan dan menjauhi segala yang dilarang oleh Allah SWT. Kedisiplinan menjadi hal yang penting karena disiplin sangat berpengaruh dalam menciptakan pribadi yang saleh sehingga mewujudkan tata kehidupan yang baik. Oleh sebab itu, Islam sangat memperhatikan pendidikan disiplin sejak usia dini. Namun sayangnya, dalam mendidik disiplin kepada anak, terkadang orangtua yang inkonsisten dalam mendisiplinkan anak yang disebabkan oleh tangisan atau rengekan anak.

\section{Sebagai teladan}

Peran ayah yang juga penting adalah peran sebagai teladan bagi anak-anaknya. Sebab, orang tua merupakan contoh pertama dan terdepan bagi anak, sehingga mempunyai pengaruh yang sangat kuat bagi anak. Apapun yang orang tua lakukan nantinya akan ditiru oleh anak. Sehingga, karakter anak akan terbangun melalui sikap dan perilaku yang ditunjukkan oleh orang tua. Tingkah laku, sikap, dan ucapan orangtua (ayah), baik di dalam dan di lingkungan luar rumah, akan diterima anak sebagai konsep berperilaku, yang kemudian akan dianggap sebagai hal yang bernilai benar. Oleh sebab itu, para orangtua (ayah) hendaknya selalu memperhatikan dan berhati-hati dalam berucap, bersikap, dan berperilaku dalam kesehariannya.

Salah satu contohnya adalah salah seorang informan yang bernama Sardjono. Beliau selalu mengajak anak laki-lakinya yang pertama untuk salat berjamaah di masjid, di mana hal tersebut biasa dilakukan ketika salat Magrib. Keteladanan dan pembiasaan yang kontinyu dan konsisten inilah yang membuat sang anak akhirnya secara otomatis pergi ke masjid ketika azan berkumandang, walaupun tanpa sang ayah. Hal ini disampaikan oleh istri Bapak Sardjono ketika berbincang disela-sela menunggu kedatangan Bapak Sardjono untuk diwawancara.

Anis (2009) menyebutkan bahwa keteladanan sebagaimana yang dituntun oleh Rasulullah SAW merupakan metode yang sangat sentral dan strategis dalam mendidik anak, termasuk dalam hal ini adalah membentuk identitas gender anak. Keteladanan Rasulullah ini telah disebutkan dalam QS. Al-Ahzab ayat 21, yaitu: 


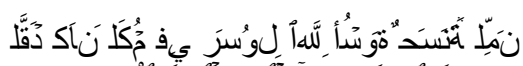

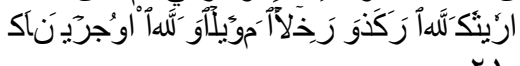

r

Terjemahan:

Sesungguhnya telah ada pada (diri) Rasulullah itu suri teladan yang baik bagimu (yaitu) bagi orang yang mengharap (rahmat) Allah dan (kedatangan) hari kiamat dan dia banyak menyebut Allah (Departemen Agama RI, 2002). Ayat tersebut merupakan dalil pokok menganjurkan kepada umat Islam (khususnya) untuk meniru atau meneladani Rasulullah SAW dalam semua ucapan, perbuatan, dan sepak terjangnya.

Selain tiga peran di atas, hal lain yang dilakukan ayah dalam membentuk identitas gender anak adalah dengan melatih dan membiasakan berpakaian sesuai jenis kelaminnya sejak usia dini, terutama untuk anak perempuan. Hal ini dilakukan salah satu keluarga di mana hal tersebut telah disepakati dan sepaham antara suami dan istri. Orangtua membiasakan anak perempuannya memakai jilbab ketika keluar rumah, walaupun hanya bermain di depan rumah dengan teman-teman sebayanya. Selain melatih anak untuk berpakaian sesuai jenis kelaminnya, hal ini pun terlihat dari cara berpakaian atau berpenampilan antara suami-istri tersebut, di mana sang istri selalu memakai jilbab pada waktu di dalam apalagi di luar rumah.

Pembiasaan yang dilakukan secara terus-menerus akan membuat hal yang terasa berat menjadi ringan (yang mulanya terpaksa menjadi sukarela). Pembiasaan tersebut akan menjadi sebuah kesadaran ketika disertai dengan penjelasan mengapa suatu hal harus dilakukan dan suatu hal tidak boleh dilakukan. Seperti yang telah dijelaskan di atas bahwa penjelasan atas suatu hal menjadi penting agar anak mengerti dan memahami atas apa-apa yang orangtua lakukan.

Selanjutnya, melalui permainan atau kesukaan anak, ayah membentuk identitas gender anak. Seperti pada umumnya, dalam pemberian permainan kepada anak, anak perempuan diberikan permainan boneka, dakon, atau bola bekel dan anak laki-laki diberikan permainan bola atau layang-layang. Tentunya pemilihan permainan tersebut tidak hanya atas dasar keinginan anak, melainkan juga telah dipilih oleh orangtua. Hal tersebut dilakukan agar anak tumbuh sesuai jenis kelaminnya dan kodratnya.

Permainan merupakan alat belajar yang membantu percepatan proses pengenalan di mana hal tersebut sebagai langkah awal memperoleh ilmu pengetahuan. Selai itu, permainan juga merupakan alat untuk menyatakan apa yang ada dalam diri, baik itu menyangkut pikiran, perasaan maupun kehendak. Rost (Anis, 2009) menyatakan bahwa permainan dapat meningkatkan perkembangan motorik, kreativitas, keterampilan sosial dan kognitif, serta motivasional dan emosional. Dengan demikian, melalui alat bermain atau mengajak anak bermain, anak berkesempatan untuk mengaktualisasikan diri, di mana hal ini merupakan kebutuhan anak yang harus dipenuhi oleh orangtua.

Selain itu, permainan juga memberi manfaat yang positif bagi pertumbuhan jasmani maupun rohani anak. Misalnya dalam bermain kelompok, anak dapat mengembangkan sikap tanggung jawab sosial, kerja sama, percaya kepada orang lain dan diri sendiri. Melalui bermain pula, orangtua dapat mengamati sifat-sifat tersembunyi dari anak, seperti sulit bekerja sama, egois, tidak jujur, dan sebagainya. Dengan mengetahui sifat-sifat tersebut, orangtua dapat mengarahkan anak dengan sebaikbaiknya (Anis, 2009). 
Melihat besarnya peran ayah dalam tumbuh-kembang anak, maka keterlibatan ayah menjadi penting dalam kehidupan anak. Seperti yang telah dijelaskan di atas, keterlibatan ayah dalam mendidik anak tidak terbatas dari aspek waktu, tetapi juga kualitas interaksi dan perhatian yang meliputi dimensi fisik, emosi, sosial, intelektual, moral, maupun otoritas. Dengan demikian, ketika seorang ayah menyadari kehadirannya sangat penting dan berarti dalam keluarga, tentunya seorang ayah tidak akan menyia-nyiakan kesempatan untuk selalu bersama keluarga dan turut dalam mengasuh serta mendidik anak.

\section{Faktor yang Mempengaruhi Peran Ayah}

Dalam melaksanakan peran ayah dalam pembentukan identitas gender anak, tentunya terdapat faktor-faktor yang mempengaruhi proses tersebut. Adapun faktor-faktor yang mempengaruhi ayah dalam menjalankan perannya berkaitan dengan pembentukan identitas gender anak, antara lain adalah sebagai berikut:

\section{Latar belakang pendidikan ayah}

Data di lapangan menunjukkan bahwa ayah yang berlatar belakang pendidikan berbasis Islam memiliki pemahaman yang lebih mengenai perannya sebagai ayah dibandingkan dengan ayah yang berlatar belakang pendidikan umum. Seperti halnya Bapak Legimo yang pernah belajar di Ma'had Ali Universitas Muhammadiyah Yogyakarta dan Bapak Sardjono yang bersekolah di instansi Muhammadiyah. Pemahaman dua informan tersebut mengenai perannya sebagai ayah tidak hanya sebatas pemenuhan kebutuhan ekonomi keluarga dan anak, melainkan juga sebagai pengayom, pelindung, dan pendidik anak serta sebagai kepala sekolah di rumahnya.
Sementara itu, tiga informan yang lainnya umumnya mempunyai pemahaman bahwa perannya sebagai ayah adalah untuk memenuhi kebutuhan ekonomi keluarga. Hal tersebut berarti bahwa tingkat pendidikan ayah tidak selalu mempengaruhi perannya sebagai ayah dalam membentuk identitas gender anak. Lebih dari itu, latar belakang pendidikan ayah lebih mempengaruhi perannya sebagai ayah dalam membentuk identitas gender anak. Hal tersebut berarti bahwa ayah yang berlatar belakang pendidikan berbasis Islam, mempunyai pemahaman yang lebih luas tentang perannya sebagai ayah dibandingkan dengan ayah yang berlatar belakang pendidikan umum. Melalui pendidikan agama, identitas sebagai laki-laki dan identitas sebagai perempuan menjadi jelas. Sebab, Islam telah memberi pedoman secara jelas bagi pemeluknya bagaimana fitrah sebagai manusia.

\section{Latar belakang etnis/budaya}

Kampung Karanganyar sebagai salah satu daerah urban di Yogyakarta menciptakan masyarakat yang hetereogen. Namun begitu, urbanisasi yang terjadi di Kampung Karanganyar tetap didominasi oleh suku Jawa yang berasal dari kota-kota di Daerah Istimewa Yogyakarta (DIY) maupun kota-kota di Jawa Tengah. Hal tersebut berarti bahwa budaya patriarki masih melekat. Oleh sebab itu, tidak heran jika data di lapangan menunjukkan bahwa umumnya peran sebagai ayah dipahami sebagai orang yang bertanggung jawab memenuhi kebutuhan ekonomi keluarga, baik itu kebutuhan pangan, papan, dan pendidikan.

Latar belakang budaya/etnis
juga berpengaruh terhadap
identifikasi ayah untuk masing-
masing gender. Dalam budaya Jawa,


citra perempuan yang ideal adalah yang memiliki sifat lemah lembut, penurut, tidak membantah, dan tidak melebihi laki-laki. Sementara itu, lakilaki yang ideal dicitrakan sebagai sosok yang serba tahu, panutan bagi perempuan, berpikir rasional, dan agresif (Raharjo (1995) dalam Putri dan Lestari, 2016). Dari indentifikasi tersebut pula, nantinya ayah akan membentuk identitas gender anak sesuai dengan apa yang anak yakini selama ini.

\section{Lamanya jam kerja}

Tingginya keterlibatan ayah dalam pengasuhan bersama sangat berkaitan dengan kelenturan jam bekerja dan kebijakan tempat kerja yang prokeluarga (Lestari, 2012). Bekerja selama 7-8 jam per hari selama enam hari dalam satu minggu, dirasa menyita waktu bagi para ayah sebagai informan untuk anak. Apalagi dengan sistem kerja shift membuat waktu informan dirasa kurang maksimal untuk dapat bersama dengan anak. Untuk menyiasati hal tersebut, para informan memanfaatkan waktu yang ada (akhir pekan dan setelah Magrib) agar dapat bersama anak, seperti membantu memandikan anak, mengantarkan ke sekolah, atau menemani bermain dan belajar.

Strazdins (Brooks, 2011) menyatakan bahwa ketika kedua orangtua bekerja di luar jam standar (bekerja malam atau di akhir pekan), informan mengalami tekanan emosi yang lebih besar dan pengasuhan yang kurang ekektif dibandingkan orangtua yang bekerja dengan waktu yang standar. Namun begitu, hal tersebut pun dialami oleh salah satu pihak (ayah atau ibu) yang bekerja pada jam nonstandar, yaitu adanya tekanan yang lebih besar, pengasuhan yang kurang efektif, serta kesulitan perilaku yang dialami anak (Stazdins dalam Brooks, 2011). Oleh sebab itu, para orangtua (ayah) harus dapat mengatur dan mengelola waktu yang dimiliki. Selain itu, penting juga untuk para ayah agar dapat mengelola stress dan tekanan pekerjaan sehingga tidak berdampak pada pelaksanaan perannya sebagai ayah.

Selain tiga faktor di atas, terdapat pula beberapa faktor lain yang mempengaruhi peran ayah dalam pembentukan identitas gender anak, antara lain adalah sebagai berikut:

\section{Kesadaran atas tanggung jawab}

Semua informan sepakat bahwa mendidik anak (termasuk membentuk identitas gender anak) merupakan tanggung jawab kedua orangtua, termasuk ayah. Para informan menyadari bahwa kewajiban seorang ayah tidak hanya sebatas mencari nafkah untuk anak dan istri, melainkan juga tanggung jawab dalam mendidik anak-anak agar menjadi anak yang sholeh/solihah dan sukses di masa depan. Hal ini diungkapkan oleh salah satu informan sebagai berikut:

"Itu kan tanggung jawab kita sebagai orangtua. Kita nggak cuma nyari duit aja. Tapi kan itu memang sudah tanggung jawab kita. Ya intinya itu tanggung jawab kita sebagai ayah ya harus berperan dalam mendidik anak" (wawancara kepada Bapak Tripurwanto).

Kehadiran anak akan memunculkan harapan dan tanggung jawab orang tua kepada anak. Rasa tanggung jawab tersebut muncul karena adanya tuntutan sosial mengenai kewajiban orangtua untuk memenuhi kebutuhan fisik maupun emosi anak, sehingga hal tersebut menuntut peran para orangtua dalam mendidik anak-anak. Selanjutnya, harapan dan tanggung jawab tersebut juga akan mempengaruhi bagaimana orangtua menciptakan situasi dan kondisi dalam mengasuh dan membesarkan anak.

Lestari menggambarkan bahwa ketika orangtua fokus pada upaya mentransfer harapan pada diri anak, maka orangtua akan berupaya 
memenuhi sarana dan prasarana yang menurut orangtua diperlukan untuk anak dalam mewujudkan harapan tersebut. Akibatnya, orangtua bersikap serba mengatur dan menuntut anak untuk patuh terhadap aturan-aturan yang telah ditetapkan. Kondisi seperti itu akan menimbulkan situasi yang penuh ketegangan, sehingga akan menimbulkan konflik orangtua-anak dalam interaksi sehari-hari. Dampak selanjutnya adalah beban berat yang ditanggung oleh orangtua dalam upaya merealisasikan harapan tersebut kepada anak (Lestari, 2012).

Sementara itu, ketika orangtua hanya terpaku pada tanggung jawab dalam mengasuh dan membesarkan anak, maka tanggung jawab tersebut diwujudkan dalam bentuk kepemilikan otoritas terhadap anak. Anak dituntut patuh dan disiplin terhadap peraturan yang ada, di mana tidak jarang model pendisiplinan yang diterapkan bersifat kaku dan keras. Situasi seperti ini akan menimbulkan peluang terjadinya tindak kekerasan terhadap anak (Lestari, 2012). Berbeda halnya ketika orangtua menjalankan tugas dan perannya berdasarkan atas kesadaran pengasuhan anak, yaitu kesadaran terhadap pentingnya peran pengasuhan anak sebagai sarana untuk mengoptimalkan tumbuhkembang anak sesuai dengan tahap perkembangannya (Lestari, 2012). Dengan demikian, adanya kesadaran tersebut akan mendorong orangtua untuk melaksanakan tugas-tugasnya sebaik mungkin sehingga kesejahteraan anak dapat tercapai.

\section{Kerjasama dan kesepakatan bersama}

Kesadaran akan tanggung jawab mendidik anak berada di tangan kedua orangtua yang menciptakan kerjasama dan kesepakatan antara suami dan istri dalam mendidik anak-anak. Kerjasama dan kesepakatan tersebut menjadi motivasi tersendiri bagi ayah dalam menjalankan tugas dan perannya dalam mendidik anak. Selanjutnya, kerjasama dan kesepakatan tersebut diwujudkan dalam bentuk pembagian tugas antara suami dan istri. Salah satu contohnya yaitu pada keluarga Bapak Sardjono, di mana suami lebih banyak mendidik anak dari sisi agama, sementara istri lebih banyak menemani anak belajar, bermain, dan bercerita (wawancara kepada Ibu Maya). Contoh lainnya adalah pada keluarga Bapak Legimo, di mana antara suami dan istri sepakat dan sepaham bahwa pembiasaan untuk menutup aurat (berjilbab bagi anak perempuan) harus diajarkan sejak dini.

Pengasuhan akan memberikan hasil yang lebih baik jika orangtua bersikap saling mendukung dan bertindak sebagai satu tim yang bekerja sama. Lestari menyebutkan bahwa secara umum dapat dikatakan bahwa tingginya keterlibatan ayah akan membuat pengasuhan bersama menjadi aktif (Lestari, 2012). Tingginya keterlibatan ayah tersebut salah satunya dipengaruhi oleh pengharapan budaya terhadap peran ideal ibu dan ayah. Pada abad ke-20 sebagian masyarakat memandang ideal peran setara antara ayah dan ibu dalam pengasuhan anak (Lestari, 2012). Budaya memberikan relung perkembangan yang mencakup (1) latar belakang fisik dan sosial bagi orangtua dan anak, (2) karakter psikologis yang dihargai oleh orangtua dan anak, dan (3) perilaku yang dianjurkan bagi anggota keluarga. Dengan demikian, budaya membentuk kisaran yang luas pada perilaku pengasuhan, mulai dari nilai umum yang diajarkan oleh orangtua 
sampai pada aspek nyata dalam keseharian (Brooks, 2011).

Kampung

Karanganyar merupakan salah satu wilayah urban di Yogyakarta di mana urbanisasi yang ada di kampung tersebut masih didominasi oleh suku Jawa. Oleh sebab itu, sedikit banyak budaya patriarki masih melekat pada masyarakat. Namun begitu, Hardjodiasastro menyatakan bahwa dalam kehidupan perkawinan masyarakat Jawa modern, sepasang suami istri harus saling menghormati dan saling berbagi peran. Suami dan istri bekerja sama dalam membuat keputusan dalam keluarga. Hal tersebut bertujuan agar tidak ada salah satu pihak yang mendominasi atau menuruti kemauannya dan ingin menang sendiri (Hardjodisastro \& Hardjodisastro dalam Putri \& Lestari, 2016).

\section{Ilmu parenting}

Semakin banyak ilmu parenting yang dimiliki seorang ayah, maka kemungkinan untuk mengambil peran semakin besar. Begitu juga sebaliknya, semakin sedikit ilmu parenting yang dimiliki ayah, maka kemungkinan mengambil peran semakin kecil. Menerapkan ilmu mendidik anak yang para ayah tahu merupakan langkah yang tepat untuk ikut berperan dalam mengasuh anak. Walaupun begitu, para ayah juga harus selalu belajar dalam mendidik anak karena dinamika sosial selalu berubah dan anak akan terus tumbuh dan berkembang. Salah satu informan pu mengungkapkan hal tersebut sebagai berikut:

“...Beda. Mungkin kalau orangtua dulu kan beda dengan yang jaman sekarang. Karna kami itu orang desa mungkin didiknya kan lain. Tapi kami... kalau sini kan ngikuti apa yang diikuti trennya... ater-aternya jaman sekarang. Tapi nggak begitu maksimal pendidikannya, apa yang kami bisa, yang kami punya, yang kami bisa jalankan. Jadi nggak bisa seperti orangtua kami. Ilmunya kami juga seperti itu kepada anakanak... kami maksimalkan, saya keluarkan semua. Terutama juga saya sampaikan kepada istri saya, apa yang kamu bisa yang baik, curahkan semua pada anak-anak. Mungkin seperti itu. Kalau yang duludulu kan cuman orangtua ngasih kepada anak kan hanya nurut aja. Untuk apanya kan nggak tahu. Tapi sekarang harus tahu anak-anak itu" (wawancara kepada Bapak Sarjono).

Hal tersebut pun disadari oleh para ayah (orantua) bahwa cara mendidik anak pada zaman sekarang berbeda dengan zaman dahulu. Meskipun sedikit banyak cara mendidik orangtua mereka dahulu terapkan, namun para ayah juga menyesuaikan dengan kondisi sekarang. Anak-anak zaman sekarang tidak cukup hanya dilarang dan diperintah tanpa diberi tahu alasan yang melatarbelakangi hal tersebut. Jika hal tersebut dilakukan, maka memungkinkan anak mencari informasi pada tempat dan orang yang salah. Tentu saja hal ini dapat berakibat buruk bagi anak. Dengan demikian, menjadi penting bagi para orang tua untuk terus belajar dan mengembangkan ilmu yang dimiliki agar proses pengasuhan anak dapat berjalan sesuai dengan tuntutan sosial dan juga perintah agama.

\section{Kebanggaan atas keberhasilan anak}

Melihat anak berhasil dalam melakukan atau mencapai sesuatu merupakan kebanggaan tersendiri untuk ayah, di mana hal tersebut menjadi motivasi ayah untuk ikut berperan serta dalam mengasuh anak. Para ayah akan merasakan peningkatan moral ketika ayah puas dengan perawatan harian dan penyesuaian diri anak (Brooks, 2011). 
Bagi sebagian orangtua, membesarkan anak berkaitan dengan kebanggaan keluarga. Para orangtua menganggap bahwa keberhasilan anak-anak (paling tidak keberhasilan menurut versi orangtua) dapat mendatangkan kepuasan tersendiri dalam diri orangtua. Para orangtua tidak jarang mengukur keberhasilan sebagai orangtua dari tingkat kesuksesan anak-anak. Namun, keberhasilan anak tidak hanya pada aspek duniawi, tetapi orangtua juga harus mengantarkan anak untuk mencapai keberhasilan akhiratnya.

\section{Kurangnya keakraban}

Sebagai akibat dari lamanya jam kerja ayah dan istri yang lebih banyak di rumah, maka hal ini bisa jadi mempengaruhi keakraban antara anak dan ayah. Selain itu, karakter dari ayah juga mempengaruhi hal tersebut. Seperti yang diungkapkan oleh Ibu Nuraeni bahwa karakter ayah yang berwibawa dan tidak teralu banyak bicara membuat anak segan dan hal tersebut menjadikan anak kurang akrab dengan ayah. Lebih lanjut lagi, beliau juga menjelaskan bahwa jenis kelamin juga mempengaruhi kedekatan tersebut. Kebanyakan anak perempuan dekat dengan ibu, sementara anak laki-laki dekat dengan ayah.

Sementara itu, Bapak Mulyanto berpendapat bahwa kurangnya kedekatan di antara ayah dan anak dikarenakan perbedaan kegiatan yang disukai oleh anak (perempuan). Bapak Mulyanto merasa kurang bisa mengimbangi permainan anak perempuannya. Padahal, ayah adalah teman bermain yang asyik bagi anak karena kebanyakan ayah mempunyai kreativitas yang lebih. Brooks menyatakan bahwa ayah yang banyak bermain dan terlibat dalam pendidikan anak akan berdampak pada berkembangnya interaksi sosial yang lebih baik bagi anak dan hubungan yang lebih interaktif dengan orangtua (Brooks, 2011). Keakraban tersebut dapat dibangun dengan cara menghabiskan waktu dengan anak untuk bersantai dan berbincang serta bermain sesuai dengan minat anak.

\section{Kesehatan mental (depresi)}

Dari lima informan yang peneliti himpun, hanya satu informan yang mengalami hal ini. Depresi yang dialami oleh salah satu informan tersebut disebabkan oleh kurangnya keterbukaan terhadap orang-orang terdekat, salah satunya dengan istri sendiri. Menurut sang istri, karakter suami yang pendiam dan semua hal dirasakan sendirilah yang menyebabkan depresi itu terjadi. Akibatnya, perannya sebagai ayah tidak maksimal dan hal tersebut banyak diambil alih oleh sang istri.

Kesehatan mental sangat penting dalam proses pendidikan. Sebab, pendidikan adalah usaha sadar untuk mentransmisikan nilai-nilai dari generasi pertama ke generasi selanjutnya. Stress dan tekanan yang tidak dikelola dengan baik akan menimbulkan depresi dan yang lebih berbahaya adalah tindak kekerasan dalam rumah tangga, baik itu terhadap istri maupun anak. Oleh sebab itu, menjadi penting untuk menjaga dan mengatur stress, tekanan, dan juga menjaga pola komunikasi yang sehat antar anggota keluarga.

\section{Simpulan Dan Saran}

Dari pemaparan di atas, dapat disimpulkan bahwa Pemahaman ayah muslim di Kampung Karanganyar mengenai perannya sebagai ayah adalah untuk memenuhi kebutuhan ekonomi, pelindung, pendidik, dan sebagai pendamping ibu. Untuk memenuhi kebutuhan ekonomi, para 
ayah muslim tersebut berusaha mencari nafkah bagi keluarga dan juga berusaha memenuhi pendidikan formal anak. Sebagai pelindung, para ayah muslim tersebut berusaha melindungi keluarga, menjamin kesejahteraan, dan kesehatan keluarga. Peran selanjutnya adalah sebagai pendidik di mana para ayah muslim tersebut mendidik anak sesuai dengan kesepakatan bersama. Terakhir adalah peran sebagai pendamping ibu di mana ayah muslim tersebut selain menjadi pasangan bagi istri juga menjadi dasar bagi istri dalam mendidik anak.

Peran ayah muslim dalam pembentukan identitas anak usia 6-8 tahun di Kampung Karanganyar meliputi teman berbagi, teladan, sumber pengetahuan, dan disciplinary. Dalam perannya menjadi teman berbagi, ayah memanfaatkan media majalah, tayangan televisi atau kejadian di sekitar sebagai pembelajaran terhadap perilaku yang boleh atau tidak boleh dilakukan. Tidak hanya itu, para ayah muslim juga memberi penjelasan agar anak memahami mengapa suatu hal boleh dan tidak boleh dilakukan. Sementara itu sebagai teladan, para ayah muslim tersebut berusaha memberi contoh pada anak tentang bagaimana seharusnya pria dan wanita berperilaku di lingkungan sosial. Sebagai sumber pengetahuan, para ayah muslim memberi bimbingan bagi anak, mulai dari mengenalkan anak dengan agama, mengenalkan anak dengan anggota keluarganya, sampai pada mengenalkan lingkungan kepada anak. Sebagai pola pendisiplinan, para ayah muslim selalu menekankan pada anak bahwa disiplin adalah hal penting untuk kesuksesan masa depan.

Faktor yang mempengaruhi peran ayah muslim terhadap pembentukan identitas gender anak usia 6-8 tahun di Kampung Karanganyar antara lain latar belakang pendidikan ayah, latar belakang etnis/budaya, lamanya jam kerja. Selain itu, faktor-faktor lain yang mempengaruhi adalah kesadaran atas tanggung jawabnya sebagai orangtua, kerja sama dan kesepakatan antara keduanya dalam mendidik anak, ilmu pengasuhan yang dimiliki ayah, kebanggaan informan ketika orangtua berhasil mendidik anak-anak, kurangnya keakraban antara informan dengan anak, serta kesehatan mental informan itu sendiri. Meskipun para ayah muslim di Kampung Karanganyar telah memahami beberapa perannya sebagai ayah, namun begitu sebaiknya para ayah muslim tersebut lebih memahami lagi tentang perannya sebagai ayah. Dengan memahami semua perannya sebagai ayah, hal tersebut berarti bahwa para ayah muslim tersebut telah mengerti identitas gender anak. Sehingga, proses pembentukan identitas gender anak akan terarah.

Selain itu, dalam membentuk identitas gender anak, sebaiknya para ayah muslim di Kampung Karanganyar memerankan diri secara seimbang antara peran sebagai teman berbagi, teladan, sumber pengetahuan, dan pengembang disiplin anak. Hal tersebut dikarenakan keberhasilan dalam mendidik anak tidak dapat dicapai hanya dengan menggunakan salah satu peran. Antara peran satu dengan peran yang saling adalah saling melengkapi. Terakhir, para ayah muslim di Kampung Karanganyar hendaknya lebih memanfaatkan waktu luangnya untuk kualitas anak. Selain itu, membangun kedekatan antara ayah dan anak juga penting, sehingga hal tersebut perlu diperhatikan oleh para ayah muslim tersebut. Terakhir adalah para ayah muslim tersebut juga harus menjaga kesehatan mental anak, karena dengan mental yang sehat, maka tugas mendidik anak akan berjalan dengan maksimal.

\section{Daftar Pustaka}

Adamsons, K., \& Jonhson, S. K. (2013). An update and expanded meta-analysis of nonresident fathering and child well-being. Journal of Family Psychology, 27(4). Diunduh pada 2 September 2015, dari psycnet.apa.org/journals/fam /27/4/589/

Akbar, R., \& Hawadi. (2001). Psikologi perkembangan anak: Mengenal sifat, bakat dan kemampuan anak. Jakarta: PT. Gramedia Widiasarana Indonesia. 
Anis, M. (2009). Sukses mendidik anak (perspektif Al-qur'an dan hadis). Yogyakarta: Pustaka Insan Madani.

Baxter, J., \& Smart, D. (2011). Fathering in Australia among couple families with young children. Australian Department of Families, Housing, Community Services and Indigenous Affairs. Occasional Paper. Diunduh pada 2 September 2014, dari http://papers.ssrn.com/sol3/paper s.cfm?abstract_id=1776522

Brooks, J. (2011). The proses of parenting. Yogyakarta: Pustaka Pelajar.

Creswell, J. W. (2010). Research design: Pendekatan kualitatif, kuantitatif, dan mixed (3th ed). Yogyakarta: Pustaka Pelajar.

Creswell, J. W. (2014). A concise introduction to mixed methods research. London: Sage Publications.

Departemen Agama Republik Indonesia. (2002). Al-Qur'an al-karim dan terjemahannya. Semarang: PT. Karya Toha Putra.

Fraenkel, J. R., \& Wallen, N. E. (1990). How to design and evaluate research in education. New York: McGraw-Hil

Graha, C. (2007). Keberhasilan anak di tangan orang tua: Panduan bagi orang tua untuk memahami perannya dalam membantu keberhasilan pendidikan anak. Jakarta: PT. Elex Media Komputindo.

Herusatoto, B. (2004). Konsepsi spriritual leluhur Jawa. Yogyakarta: Ombak.

Hurlock, E. B. (1978). Perkembangan anak (Vol. 2). Jakarta: Erlangga.

Kamila, I. I., \& Mukhlis. (2013). Perbedaan harga diri (self-esteem) remaja ditinjau dari keberadaan ayah. Jurnal Psikologi, 9(2).

Khoirunnisa \& Setyawan, I. (2014). Hubungan antara persepsi terhadap peran ayah dengan pengungkapan diri pada remaja awal. Jurnal Empati, 3(4).

Kusumah, I., \& Fitrianti, V. (2012). The excellent parenting: Mendidik anak ala rasulullah. Yogyakarta: Qudsi Media.

Lestari, S. (2012). Psikologi keluarga: Penanaman nilai dan penanganan konflik dalam keluarga. Jakarta: Kencana.

Makusha, T, Richter, L, Knight, L, Rooyen, H. V., \& Bhana, D. (2013). "The good and the bad?" childhood experiences with father and their influence on women's expectations and men's experiences of fathering in Rural KwaZulu-Natal, South Africa. Journal of Fathering, 11 (2). Diunduh pada 2 September 2015, dari

http://search.proquest.com/openvi ew/b628f91b 65c9fa9a5680f7000c74efa7/1?pqorigsite $=$ gscholar

Purwandari, E. (2015). Figur orang tua dengan gender: Cross sex Telaah kasus remaja beresiko penyalahgunaan NAPZA. Proceeding Seminar Nasional. Diunduh pada 10 Februari 2016, dari https://publikasiilmiah.ums.ac.id/h andle/11617/6542

Putri, D. P. K., \& Lestari, S. (2016). Pembagian peran dalam rumah tangga pada pasangan suami Istri Jawa. Jurnal Penelitian Humaniora, 16(1). Diunduh pada 23 November 2016, dari 
http://journals.ums.ac.id/index.php/ humaniora/article/view/1523

Rahman, A. (2015). Ensiklopedi Muhammad saw: Muhammad sebagai suami dan ayah. Bandung: Pelangi Mizan.

Reber, A. S \& Reber, E. S. (2010). Kamus psikologi. Yogyakarta: Pustaka Pelajar.

Setyawati \& Rahardjo, P. (2015). Keterlibatan ayah serta faktorfaktor yang berpengaruh dalam pengasuhan seksualitas sebagai upaya pencegahan perilaku seks pranikah remaja di Purwokerto. Proceeding Seminar LPPM UMP. Diunduh pada 10 Februari 2016, dari

http://www.seminarlppm.ump.ac.id /index.php/semlppm/article/view/ 160

Shihab, M. Q. (2002). Tafsir Al-Mishbah: Pesan, kesan dan keserasian alqur'an (Vol. 11). Jakarta: Lentera Hati.

Sundari, A. R., \& Herdajani, F. (2013). Dampak fatherless terhadap perkembangan psikologis anak. Proceeding Seminar Nasional Parenting. Diunduh pada 10 februari 2016, dari https://publikasiilmiah.ums.ac.id/bi tstream/handle/11617/3973/A23. pdf?sequence $=1$

Suwaid, M. N. A. H. (2010). Prophetic parenting: Cara nabi saw mendidik anak. Yogyakarta: Pro-U Media.

This is Gender. (n.d). Workshop quranic parenting ibu kembali ke rumah. Diunduh dari http://thisis gender.com/workshop-quranicparenting-ibu-kembali-ke-rumah/

Wahyuningrum, E. (2011). Peran ayah (fathering) pada pengasuhan anak usia dini. Psikowacana, 11(1). Diunduh pada 10 Februari 2016, dari

http://ris.uksw.edu/jurnal/read/ko de/j00778

Yuniarto, B. (2013). Membangun kesadaran warga negara dalam pelestarian lingkungan. Yogyakarta: Deepublish. 